\title{
The Student Responses to the Use of Automatic Screencast (SOM) in Online Learning
}

\author{
Jelita*, Fenny Anggreni, Mazlan \\ IAIN Langsa \\ Aceh, Indonesia \\ *jelita@iainlangsa.ac.id
}

\begin{abstract}
This study investigated students' responses and obstacles on the application of Screen-Cast O Matic (SOM) for an Online Learning Environment (OLE) because of health protocol for Covid-19 Pandemic in Kota Langsa. The study employed a descriptive qualitative approach to describe the advantages of SOM in OLE. The study applied a purposive sampling technique to address the 96 of the fourth-semester students of Pendidikan Guru Madrasah Ibtidaiyah (PGMI) Department of IAIN Langsa. Throughout the population, 75 students actively engaged on SOM who were proposed to be the study samples. To collect the data, the researcher shared online open and closed questionnaire forms consist 15 statement items via Online Google Forms which later on were assessed with Linkert Scales for 4 alternative responses. The set of Open questionnaires projected 2 questions to mainly describe the students' obstacles on SOM applications in OLE. Moreover, for the closed questionnaires, 4 alternative responses indicated the grid of students' learning motivation, self-confidence, material comprehension, the advantages of SOM in the tutoring section which targeting lecturers. The questionnaires were scaled into 3 criteria; Very Good, Good, and Not Good. The result anticipated the students' responses on SOM in OLE which estimated positively to motivate students' learning $(67.56 \%)$; to help in material comprehension $(\mathbf{8 5 . 6 7 \%})$, to increase self-efficacy $(79.67 \%)$, and to prove its usefulness and supportive $(66.67 \%)$ in OLE of health protocol for Covid-19 Pandemic in Kota Langsa. In conclusion, the SOM proves great software assistance to improve students' communication and delivery for learning material in OLE during pandemic protocol which insists to conduct social distance in teaching-learning.
\end{abstract}

Keywords-Covid-19 pandemic, Screencast O-Matic, online learning environment

\section{INTRODUCTION}

The world faces the Coronavirus Disease (Covid -19 virus) as a pandemic, including in Indonesia. This pandemic threatens human life, which disrupts many sectors, particularly education that involves reducing community interaction, which is a paradox since education is carried on a collective of people in a community. The government initiates to campaign to reduce the pandemic exposure by spraying disinfectants, using masks, washing hands, social and physical distancing as well as Large-Scale Social Restrictions (PSBB). However, the virus exposures rapidly infected Indonesian citizens. The initiation of PSBB lead to the Online Learning Environment (OLE) requested the educational beneficiaries; Teachers, Students, and So on, to stay, work, and learn at a home program [1]. It is conducted to meet the recommendation of the Indonesian Minister of Education and Culture No. 3 of 2020, which concerns the prevention and handling of Covid-19 health protocols in Educational Institution, and No. 4 which concerns the implementation of Educational Policy with Emergency Protocols period of the Pandemic exposures, all in one, to suggest OLE for learning-teaching from home.

Referring to the Minister of Education and Culture recommendation No. 36962/MPK.A/ HK / 2020 concerning implementing online learning from home via video conferencing, digital documents, and other online means and Circular Letter Number 1 of 2020 concerning the prevention and spread of Corona Virus Disease (Covid-19) in Higher Education, the Ministry of Education and Culture states that the implementation of distance learning is following the conditions of the university and advises students to do learning from home with online learning both through google classrooms and recording material in video form through Screencast $O$ Matic [2]. This action executed to reduce the pandemic outbreak in Indonesia that is currently ravaging and break the chain of the spread of covid-19. Therefore, it is distance learning to be a solution to the current learning conditions.

The Faculty of Tarbiyah and Teacher Training, IAIN Langsa, is one of the faculties that applies distance learning. The implementation of distance learning activities utilizes internet-based learning media known as learning online. In learning online, students and lecturers do not meet face-to-face but through a mutual agreement that can be done from anywhere and at any time according to the specified schedule [3] to carry out this online learning requires ICT-based media. However, based on observations it was found that in online learning there were still some lecturers who used the WhatsApp group predominantly as a place for the learning process and collected assignments without face to face online. Besides, it does not invite students to practice communication skills as is done in offline learning. As a result, students become lazy to think, less skilled in communication and in using ICT-based media. It is feared that students will miss out 
on ICT technology. Therefore, it is necessary to use media that can be used to deliver the subject matter in online learning. The media that can be used is the application Screencast $O$ Matic (SOM).

The application Screencast $O$ Matic is software that functions to record all activities carried out on the computer screen. Screencast $O$ Matic as a learning video creation, because it is easy to obtain and easy to learn [4]. Furthermore, Suryanto and Sumbawati [5] stated that the application screencast o Matic (SOM) is an e-learning media that can record all learning activities in the form of video tutorials that can change the learning atmosphere such as face to face in class. The lecturer creates a learning video containing the contents of the lecture material and is uploaded to YouTube so that students can upload it anywhere and anytime, which allows students to find a comfortable situation for them to study. Sosen shares the link with the group students' WhatsApp account aims to discuss the obstacles faced by students. The video used through the SOM contains assignments that must be done by students accompanied by steps for using the SOM application. Through this assignment, students are free to convey their ideas without any shame in themselves. OLE is expected to overcome the problems that occur today as a substitute for face-to-face learning.

In online learning, students will be more active in looking for learning resources via the internet independently and can help students feel confident in communicating. This ability will foster creativity to think creatively in solving problems [6]. In this study, the use of automatic screencasts (SOM) in online learning was carried out in the Basic Natural Science course. Many studies that have been conducted by previous researchers on screencast o Matic (SOM), among others [7] found that student learning outcomes using media Screencast-O-Matic in integral calculus courses were better than student learning outcomes using conventional learning. Based on the description above, the authors are interested in knowing about student perceptions of the use of screencast automatic (SOM) in online pursuits and the constraints faced by students in online learning.

\section{Methodology}

The study described a qualitative investigation students' response on the use of the application Screencast-O-Matic (SOM) in OLE. The population used in the study were all students of PGMI semester IV FTIK IAIN Langsa, totaling 96 people. Sampling was used with the technique purposive sampling. The students who play an active role in using SOM are 75 people so that all of them are used as research samples. The Data collection was carried out online via a google form. The instrument used was in the form of an open questionnaire and a closed questionnaire on a Likert scale with 4 choices totaling 15 statement items. Closed questionnaires are arranged based on a grid of 4 response indicators, including student learning motivation, self-confidence, understanding of the material, and the benefits of SOM in lectures. A set of open questionnaires totaling 2 questions in the form of structured descriptions that measure the constraints faced by students in using the SOM application and implementing online learning. The results of the questionnaire were analyzed using the percentage formula and interpreted by 3 criteria, namely very $\operatorname{good}(77 \%-100 \%), \operatorname{good}(34 \%-76 \%)$, and not $\operatorname{good}(0-33 \%)$

\section{RESULTS AND DISCUSSIONS}

During the Covid-19 pandemic, the implementation of learning in the world of education changed drastically from face-to-face learning to online learning. This is done to break the chain of the covid 19 viruses. For the learning process to continue, an application is needed that helps an effective learning process so that it can motivate students. However, its implementation requires supporting facilities and infrastructure. The online learning platform that is used whether or not it needs student responses to the application used. The results of student responses can be measured using a questionnaire via a google form. From the results of the questionnaire analysis, data was generated about student responses to the use of automatic screencasts in online learning during the pandemic and the obstacles faced by students in terms of the use of the application automatic screencast and the implementation of online learning during the pandemic. Therefore, the finding described on these following points:

\section{A. Student Response to the Use of the Screencast Automatic Application (SOM)}

The Student responses from FTIK IAIN Langsa regarding the use of the screencast automatic (SOM) application in the implementation of online learning are measured in four indicators through a closed questionnaire and an open questionnaire. From the results of a closed questionnaire analysis of student responses to the use application screencast of the online learning (SOM) on each indicator, the following data were obtained.

1) Learning motivation: Motivation is indispensable in learning. With motivation, students will be more interested in learning the material provided in learning that will have an impact on learning outcomes. To grow motivation to learn during a pandemic, it is very necessary so that students are not bored with online learning. Educators are encouraged to design learning so that online learning is felt by students like face-to-face learning. The alternative used is the use of online learning platforms, namely Screencast O Matic (SOM). In using the SOM platform, students are required to be able to have the skills to use computer technology in advance to compile the material to be delivered through PowerPoint which is then presented via video where students can develop their creativity in explaining the material to be delivered. The motivation to use SOM causes them to be more confident about uploading SOM this is under research [8]. The use of YouTube in learning can increase student interest in learning. The results of student responses about the application 
screencast automatic (SOM) in online lectures during the pandemic are shown in Figure 1 below.

\section{THE LEARNING MOTIVATION} PERCENTAGES

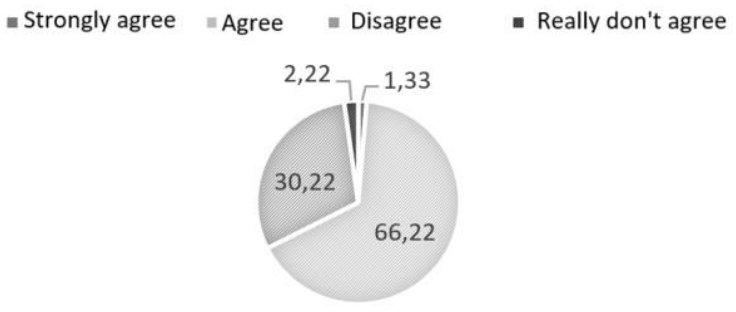

Fig. 1. Screencast-O-Matic for the students' learning motivation.

From the above results, it can be concluded that the use of an automatic screencast can motivate students to do digitalbased learning. In the use of the SOM application, the video displayed displays the sound, images, and gestures of the speaker. The learning videos shown can attract students' attention so that other students do not get bored with the material provided and encourage student motivation, interest, and memory. This is following the results of research conducted Utami et al. [9] that the use of video in the form of animation can motivate student learning. Besides, the skills students have in developing SOM are an indicator of a student's ability to use computer technology. Based on research Enriquez's [10], that learning using computers can motivate student learning better.

2) Learning material comprehension: The students' material comprehension is the key to the success of using applications in online learning. For the material to be conveyed well and easily accepted by other students, it is necessary to have systematic planning in compiling SOM. Students need to know the keywords of the material presented so that what will be conveyed is under the objectives to be achieved. From the results of the SOM analysis, there are still students who have not been able to determine the important components of the material presented so that SOM as a tool for conveying information has not been able to optimally assist students' understanding of the material. Although more than some students stated that SOM can help in understanding the material presented $(75.67 \%)$. This can be seen from the results of the percentage of the questionnaire from the following figure:
MATERIAL COMPREHENSION(\%)

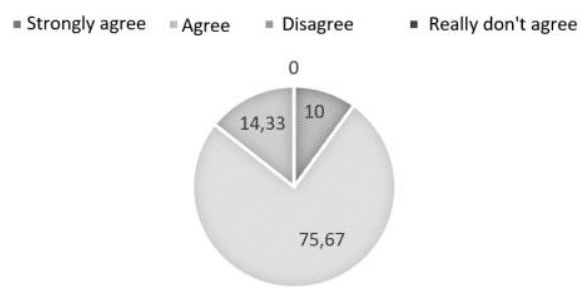

Fig. 2. The Screencast-O-Matic on students' material comprehension chart.

Based on Figure 2 it can be concluded that the use of Screencast-O-Matic is great for understanding material in online learning. This is because the O Matic Screencast has systematic steps that are easy for students to understand, the material presented, and it's supporting components so that the Screencast-O-Matic will increase students' knowledge in the learning process [11]. Furthermore Suryanto and Sumbawati [5] stated that the use of the method e-learning through social media can improve student learning outcomes. The understanding of the material obtained by students is because before using SOM, students first read the material and summarize it in the form of PowerPoint which is presented again in the form of a video so that students repeat themselves to study the material presented. Repetitive work will foster memory and understanding of concepts. This is under the research of Enriquez [10], which reported that computer-based assignments were able to improve student understanding and increase high retention rates.

3) Self-efficacy: Self-efficacy is a person's belief in controlling himself in various conditions so that he can control his behavior to improve his learning achievement [12]. With self-confidence, students will be able to construct their knowledge so that they can master the subject matter and skills. From the research results, it was found that the use of SOM was able to help students increase their confidence in OLE. The existence of this belief causes student selfconfidence. The results of a questionnaire about student selfefficacy are shown in Figure 3 below:

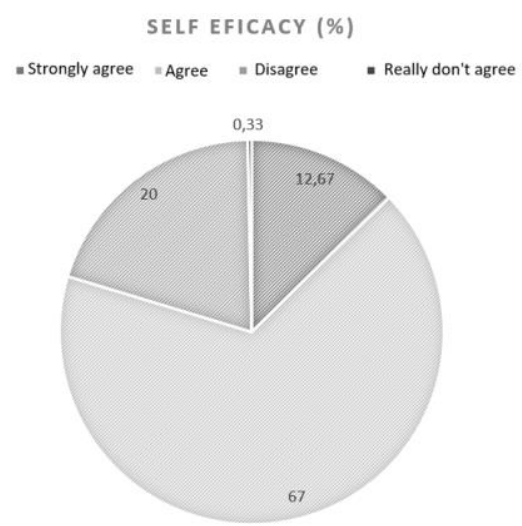

Fig. 3. Screencast O Matic on establishing the students' self efficacy. 
From Figure 3 above it can be concluded that the use of the Screencast $\mathrm{O}$ Matic application in lectures is good for student self-confidence by $67 \%$. Self-confidence causes students to be able to do the assignments given by the lecturer. The results of the study [13] reported that students who have low beliefs will often experience failure in learning, easily give up and participate less in learning. On the other hand, if students have high confidence, all given tasks can be completed easily and responsibly [14]. Higher self-confidence is important to overcome discouragement for students, which enables them to explore their abilities according to the skills they have. The preparation of material that has been prepared in SOM gives a sense of calm to students to appear to explain the existing material. This condition makes students feel comfortable and have the confidence to present the material through the Screencast-O-Matic. Self-confidence motivates learning so that students can understand lecture material.

4) The benefit of Screencast-O-Matic (SOM) in OLE: The processes are carried out using the internet network without face-to-face contact between educators and students. Online learning requires applications such as SOM to provide material and assignments. All learning activities are carried out online. Presentation assignments can be delivered using SOM. Through this application, students can convey the knowledge they have. However, communication cannot be carried out interactively and only takes place in one direction. The SOM application is a tool that cannot be used for two-way applications between educators and students. The SOM is used with the help of other platform applications to allow two-way communication to occur. The results of student responses show that the use of Screencast O Matic (SOM) in online lectures is good for online lectures. The questionnaire result data can be shown in Figure 4 below.

THE SOM APPLICATION FOR OLE

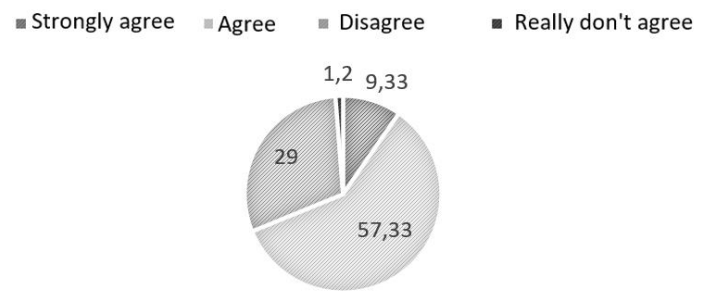

Fig. 4. The Screencast-O-Matic for OLE.

From Figure 4 it is concluded that the use of $\mathrm{O}$ Matic Screencasts can help in Online Lectures. This is supported by the results of research Kholifah [15], Suryanto and Sumbawati [5] which state that the Screencast O Matic media is very well used in the learning process. Even though there are obstacles faced by students in their use, such as unsupported networks, requiring quotas, and laptops. The use of this SOM application must be supported by these components. In general, the responses of FTIK IAIN Langsa students to the use of the application Screencast O Matic (SOM) in online lectures can be shown in Table 1 below.

TABLE I. RECAPITULATION OF QUESTIONNAIRE RESULTS ABOUT THE USE OF SCREENCAST O MATIC (SOM) IN ONLINE LECTURES

\begin{tabular}{|c|l|c|c|c|c|}
\hline No & Indicator & SS & S & TS & STS \\
\hline 1 & Motivation & 1.33 & 66.22 & 30.22 & 2.22 \\
\hline 2 & Comprehension & 10.00 & 75.67 & 14.33 & 0.00 \\
\hline 3 & Self-Eficacy & 12.67 & 67.00 & 20.00 & 0.33 \\
\hline 4 & Advantages & 9.33 & 57.33 & 29.00 & 4.33 \\
\hline \multicolumn{2}{|c|}{ Total } & $\mathbf{3 3 . 3 3}$ & $\mathbf{2 6 6 . 2 2}$ & $\mathbf{9 3 . 5 5}$ & $\mathbf{6 . 8 8}$ \\
\hline \multicolumn{2}{|c|}{ Percentage Avarages } & 8.33 & 66.56 & 23.39 & 1.72 \\
\hline \% Total & \multicolumn{3}{|c|}{$\mathbf{2 5 . 1 1}$} \\
\hline
\end{tabular}

From Table 1 it appears that the student response to the use of SOM in online lectures is $74.89 \%$ with a good category. However, there are still some people who claim that the use of Screencast O Matic (SOM) is not good for online lectures. In general, it can be concluded that the application Screencast $\mathrm{O}$ Matic can be used in online learning. This is because this application is a combined media between PowerPoint, video, and YouTube. The use of media in the form of videos in learning can attract students' attention to the material presented so that students are motivated and more enthusiastic in learning activities [16]. Moreover, the videos shown are the result of student creativity by showing their faces. Students can selfassess the results of their work so that they can find solutions to the deficiencies they display. The media used by students independently can be used as a learning resource. According to the research results Kholifah [15] that video media learning through screencast o Matic with a contextual approach is better than conventional learning. The use of SOM is also useful for training students' speaking skills so that later they will be able to communicate existing ideas and be able to foster a sense of confidence in themselves.

\section{B. Student Constraints in using SOM}

Even though SOM can be used in learning, there are still some people who claim that SOM is not useful in online learning. In using it, many obstacles occur in the field. From the results of an open questionnaire through a google form, it was found that in general the obstacles faced by students in using automatic screencast in online learning were influenced by internal factors such as internet quota costs, skills in making SOM, computer ownership, and external factors such as inadequate internet networks. The results of the data analysis can be shown in Table 2 below.

TABLE II. CONSTRAINTS FACED IN USING SOM

\begin{tabular}{|l|c|c|}
\hline \multirow{2}{*}{\multicolumn{1}{|c|}{ The Constraints }} & \multicolumn{2}{|c|}{ Open Questionairee Statements } \\
\cline { 2 - 3 } & $\begin{array}{c}\text { SOM Application } \\
(\mathbf{\%})\end{array}$ & $\begin{array}{c}\text { OLE execution } \\
(\%)\end{array}$ \\
\hline Did not own a laptop & 32,00 & - \\
\hline The Students' Skill to develop & 30,67 & - \\
\hline SOM Materials Comprehension & 21,33 & - \\
\hline Quota Credits & 6,67 & 53,33 \\
\hline Internet link & 9,33 & 46,67 \\
\hline
\end{tabular}


Table 2 displayed that the biggest obstacle faced by students in using screencast automatic (SOM) in online learning is the lack of facilities owned by students such as the absence of laptops (32\%) and The lack of student skills in using information and communication technology (ICT) is $30.67 \%$. Thus, it is concluded that the use of SOM in online learning is needed both internal and external facilities and infrastructure such as the ability to use computers. According to Muhammad et al. [17] states that the ability to use ICTs is critical to success in the learning process. Thus through this online learning student activity becomes more enhanced than face-to-face learning and will provide a personal experience for students [18].

Based on the results of the questionnaire, it was found that the obstacles faced by students in online learning were inadequate internet networks, especially students in villages. This is because the student residences are in remote areas, making it difficult to get a good network. Also, the biggest obstacle is the high cost of quotas for attending lectures. Online learning is carried out for all courses so that quota costs increase so that some students are reluctant to attend lectures because they do not have the cost to buy internet quotas. This is because their parents do not have the money due to the pandemic. Many parents of students have lost their jobs or have reduced their income due to covid-19. Thus it can disrupt the online learning process carried out. They also argue that faceto-face learning is better than online learning, especially in understanding the material. This is because in online learning the interaction of educators and students is limited and communication is difficult to do to ask questions about things that are considered difficult for students, even though it has been explained that Nampun still does not understand what the educators explain. In online learning, students learn more independently. Independent learning is good in learning to foster a sense of responsibility and self-confidence. However, students are less able to interpret the material presented so that students find it difficult to understand the existing material. This is because students are used to depending on their classmates so that they are less able to solve problems if they do not have friends to discuss.

\section{CONCLUSIONS AND SUGGESTIONS}

Based on the results of the study, it shows that there is a positive response from students to the use of screencast o Matic (SOM) in online learning in the Basic Natural Science course during the Covid-19 pandemic. The students participated in making screencasts o Matic in presenting their given assignments. The use of the SOM application in online learning helps them interact with lecturers and between students, be more confident, especially in presentations, and is useful as an alternative to offline learning during the pandemic. However, the obstacle found in using automatic screencasts is that it requires expensive costs to purchase internet quota and an inadequate network. Therefore, it is hoped that related institutions will provide adequate internet quota assistance to support the smooth running of online learning. Besides, it is necessary to do further research on the effectiveness of using the application Screencast O Matic (SOM).

\section{ACKNOWLEDGMENTS}

Thank you to the head of the IAIN Langsa Research and Community Service Institute for providing the opportunity and support for us to take part in the 2020 research grant at the Indonesian Ministry of Religion's lintapdimas.

\section{REFERENCES}

[1] D. Jamaluddin, T. Ratnasih, H. Gunawan, and E. Paujiah, "Pembelajaran daring masa pandemik Covid-19 pada calon guru: hambatan, solusi dan proyeksi,” Bandung: LP2M, UIN Sunan Gunung Djjati Bandung, 2020, p. $1-10$.

[2] Kementerian Pendidikan dan Kebudayaan Republik Indonesia, "Sura Edaran Menteri Pendidikan Dan Kebudayaan Republik Indonesia Nomor 35952/MPK.A/HK/2020.” Jakarta: Kemendikbud, 2020.

[3] S. Zuriati and B. Briando, Persepsi Siswa Terhadap Pembelajaran Online Di Masa Pandemi Pada Sekolah Menengah Atas Negeri Empat Tanjungpinang, 2020. In Proceeding Webinar dan Call for Papers "Menyongsong $\quad$ Era Merdeka Belajar' https://www.researchgate.net/publication/3423300 09

[4] K. Wirahyuni, Pemanfaatan Screencast-O-Matic Dalam Pembelajaran Ict Bahasa Indonesia. In Prosiding Seminar Nasional PBSI UPY 2019 (Vol. 1, No. 1, pp. 49-55), 2019

[5] H. Suryanto and M.S. Sumbawati, "Pengembangan Multimedia ELearning Berbasis Screencast-O-Metic Pada Pembelajaran Matematika Untuk Siswa Sekolah Menengah Pertama Kelas VII." Jurnal Teknologi Pembelajaran Devosi, vol. 5, pp. 11-21, 2015.

[6] M. Masnipal, Menjadi Guru PAUD Profesional. Bandung: Remaja Rosdakarya, 2018

[7] S.V. Dewi, "Efektivitas Penggunaan Media Screencast O-Matic Pada Mata Kuliah Kalkulus Integral Terhadap Hasil Belajar Mahasiswa.” Jurnal Penelitian Pendidikan Dan Pengajaran Matematika, vol. 2, pp. 61-66, 2016.

[8] J. Jelita, Y. Suzana, and N. Nuraida, "Peningkatan Aktivitas Belajar Siswa dalam Pembelajaran IPA melalui Lesson Study," JIPI (Jurnal IPA \& Pembelajaran IPA), vol. 4, pp. 81-91, 2020.

[9] D.L. Utami, Y. Wibowo, and T. Rahayu, "Penyusunan Media Pembelajaran Video Animasi Sistem Saraf Untuk Meningkatkan Motivasi Belajar Siswa Kelas XI SMA Negeri 1 Kasihan Bantul.” Jurnal Prodi Pendidikan Biologi, vol. 6, pp. 39-46, 2017.

[10] M.A.S. Enriquez, Students' Perceptions on the Effectiveness of the Use of Edmodo as a Supplementary Tool for Learning. In DLSU Research Congress (pp. 1-6), 2014.

[11] R. Davis, "Retooling Perspectives on Technology's Role in Language Educationtle." Studies in SelfAccess Learning Journal, vol. 2, pp. 212 $18,2011$.

[12] D. Chang and W.C. Chien, Determining the relationship between academic self-efficacy and student engagement by meta-analysis. In 2nd International Conference on Education Reform and Modern Management (ERMM 2015) (pp. 142-145), 2015.

[13] D. D. Sagita, D. Daharnis, and S. Syahniar, "Hubungan Self Efficacy, Motivasi Berprestasi, Prokrastinasi Akademik Dan Stres Akademik Mahasiswa," Bikotetik (Bimbingan dan Konseling Teor. dan Prakt., vol. 1, no. 2, p. 43, 2017.

[14] E. A. Linnenbrink and P. R. Pintrich, "The role of self-efficacy belief in student engagment and learning in the classroom," Read. Writ. Q., vol. 19, pp. 119-137, 2003. 
[15] S. Kholifah, "The Development of Learning Video Media Based on Swishmax and Screencast O-Matic Software through Contextual Approach.” Dinamika Pendidikan, vol. 11, pp. 67-74, 2016.

[16] R.R. Ekasari, G. Gunawan, and H. Sahidu, "Pengaruh Model Pembelajaran Langsung Berbantuan Media Laboratorium Terhadap Kreatifitas Fisika Siswa SMA.” Jurnal Pendidikan Fisika Dan Teknologi, vol. 2, pp. 106, 2017.
[17] H. Muhammad and Y. Rahim, "Pemanfaatan Ict Sebagai Media Pembelajaran Dan Informasi Pada Uin Alauddin Makassar." Vol. 6, pp. 127-35, 2011

[18] O. B. Adedoyin and E. Soykan, "Covid-19 pandemic and online learning: the challenges and opportunities," Interact. Learn. Environ., 1$13,2020$. 